\title{
PENGEMBANGAN KEMAMPUAN MOTORIK KASAR ANAK MELALUI KEGIATAN SENAM CERIA
}

\author{
Nuryanti ${ }^{1}$ \\ Robandi Roni ${ }^{2}$ \\ Helmi Ismail $^{3}$
}

\begin{abstract}
ABSTRAK
Permasalahan dalam penelitian ini adalah pengembangan kemampuan motorik kasar anak yang belum baik. Proses kegiatan pembelajaran lebih terpaku pada kegiatan membaca, menulis dan berhitung sehingga untuk kemampuan motorik anak kurang ditingkatkan. Maka dari itu penelitian dilaksanakan untuk pengembangan kemampuan motorik kasar anak melalui kegiatan senam yang dikhususkan untuk kelompok A. Jumlah anak pada penelitian ini adalah 5 orang, terdiri dari 1 anak perempuan dan 4 anak laki-laki. Pengembangan kemampuan motorik kasar anak dilakukan melalui kegiatan senam ceria yang menarik dan mudah ditiru oleh anak sehingga tidak menyulitkan anak. Selain itu kegiatan senam ini dilakukan dengan iringan irama tamborin dan irama musik/lagu yang ceria, serta anak dipakaikan properti saat senam. Dalam pelaksanaannya, peneliti menggunakan metode penelitian tindakan kelas dengan desain penelitian model John Elliot. Instrumen yang digunakan yaitu, penilaian performa, observasi, catatan lapangan, wawancara. Berdasarkan hasil pelaksanaan kegiatan senam ceria terdapat pengembangan yang lebih baik. Pengembangan kemampuan motorik kasar dalam indikator mengikuti gerakan senam sesuai dengan irama pada siklus I sebesar 48\%, sedangkan pada siklus II teijadi pengembangan yaitu sebesar $72 \%$, dan siklus III semakin meningkat sebesar 89\%. Dalam indikator menggerakan kepala, tangan dan kaki secara terkoordinasi sesuai irama pada siklus I sebesar $44 \%$, pada siklus II teijadi pengembangan sebesar $68 \%$, dan siklus III semakin meningkat menjadi $91 \%$. Dalam indikator mengekspresikan gerakan senam sesuai dengan irama musik, pada siklus I sebesar $43 \%$, pada siklus II terjadi pengembangan $65 \%$, dan siklus III semakin meningkat menjadi 89\%. Maka dapat disimpulkan bahwa melalui kegiatan senam ceria kemampuan motorik kasar anak meningkat. Hal ini dapat dilihat dari proses dan performa pada saat penelitian.

Kata Kuci: Kemampuan Motorik kasar, Senam ceria
\end{abstract}

\footnotetext{
${ }^{1}$ Kunuy20@yahoo.com

${ }^{2}$ Dosen Kampus UPI Cibiru

${ }^{3}$ Dosen Kampus UPI Cibiru
} 


\section{A. PENDAHULUAN}

Anak usia dini merupakan anak yang berada pada usia 0-6 tahun. Usia dini merupakan usia yang sangat penting bagi perkembangan anak sehingga dapat disebut dengan usia golden age. Anak usia dini sedang dalam tahap pertumbuhan dan perkembangan yang paling pesat, baik fisik maupun mental.

Pada anak usia 0-6 tahun hendaklah memberika layanan pendidikan dengan baik, karena masa itu lah anak dapat di rangsang segala apek perkembangannya. Maka dari itu untuk memfasilitasi anak usia dini maka pemerintah menyediakan beberapa lembaga pendidikan pendidikan anak usia dini, yang dimana pendidikan anak usia dini merupakan salah satu bentuk penyelenggara pendidikan yang menitik beratkan pada peletekkan dasar ke arah pertumbuhan dan perkembangan fisik (koordinasi motorik halus dan kasar), kecerdasan, sosial emosonal, bahasa dan komunikasi sesuai dengan tahap-tahap perkembangan yang dilalui oleh anak usia dini. Pendidikan anak usia dini ini merupakan sebuah pendidikan yang dilakukan pada anak yang baru lahir hingga enam tahun.

Pendidikan anak usia dini ini sudah tertera dalam Undang-unadang 20 Tahun 2003 tentang sistem Pendidikan Nasional berkaitan dengan pendidikan Anak Usia Dini pada Bab 1 pasal 1 ayat 14 ditegaskan bahwa: Pendidikan Anak Usia Dini adalah suatu upaya pembinaan yang ditunjukan kepada anak sejak lahir sampai dengan usia enam tahun yang dilakukan melalui pemberian rangsangan pendidikan untuk membantu pertumbuhan dan perkembangan jasmani dan rohani agar anak memiliki kesiapan dalam memasuki pendidikan lebih lanjut.

Maka dari itu pendidikan untuk anak usia dini ini memiliki jalur dan jenjang pendidikan yaitu, jalur formal dan non formal. Dan salah satu jalur formal ialah TK (tamana kanak-kanak). Menurut Abidin (2009, hlm. 103) mengemukakan 'Taman Kanak-Kanak adalah salah satu bentuk satuan pendidikan anak usia dini pada jalur formal yang menyelenggarakan program pendidikan bagi anak usia 4-6 tahun'. Dalam hal ini anak usia 4-6 tahun ini di bagi ke dalam dua kelompok, untuk usia 45 tahun dikelompokan ke dalam kelompok A sedangkan untuk anak usia 56 tahun di kelompokan ke dalam kelompok B. Pembagian kelompok tersebut bertujuan agar pembelajaran yang dibeikan dapat disesuaikan dengan karakteristik anak, karena tahapan perkembangan anak berbeda-beda maka tahapan perkembangan anak yang harus dicapai pun berbeda-beda pula dan di sesuaikan dengan usia anak.

Beberapa aspek perkembangan anak yang dapat dikembangkan untuk anak usia dini di antaranya aspek moral, agama, sosial emosional, bahasa, kognitif serta fisik motorik. Mengingat banyak aspek perkembangan yang harus dimiliki oleh anak, maka rangsangan dan stimulus yang diberikan oleh guru harus tepat. Saperti salah satu contoh aspek perkembangan yang perlu dikembangkan pada anak pada anak adalah aspek fisik motorik. Kemampuan fisik motorik anak merupakan salah satu hal yang penting untuk perkembangan anak. Karena pada masa tersebut anak mempunyai potensi yang sangat besar untuk mengoptimalkan segala aspek perkembangannya, termasuk perkembangan motoriknya. Motorik pada umumnya gerakan-gerakan yang biasa dilakukkan anak, bisa kita lihat pada saat anak melakukan aktifitas bermain.

Perkembangan motorik merupakan proses tumbuh kembang kemampuan 
gerak seorang anak. Setiapp gerakan yang dilakukan anak merupakan hasil dari pola interaksi yang kompleks dari berbagai bagian dan sistem dalam tubuh yang dikontrol otak.

Pembangan motorik berarti perkembangan pengendalian gerak jasmani melalui kegiatan pusat syaraf, urat, dan alat yang terkoordinasi dalam tubuh. Dalam buku "Anak Prasekolah (2000)" (dalam Sujiono, 2007, hlm. 1.3) tertulis bahwa, masa lima tahun pertama adalah masa pesatnya perkembangan motorik anak. Motorik adalah semua gerakan yang mungkin didapatkan oleh seluruh tubuh, sedangkan perkembangan motorik dapat disebut sebagai perkembangan dari unsur kematangan dan pengendalian gerak tubuh.

Perkembangan motorik ini erat kaitanya dengan perkembangan pusat motorik di otak. Keterlampilan motorik berkembang sejalan dengan kematangan otak dan syaraf. Oleh sebab itu, setiapp gerakan yang dilakukan anak sesederhana apapun, sebenarnya merupakan hasil pola interaksi yang kompleks dari berbagai bagian dan sistem dalam tubuh yang dikintrol otak. Maka dari itu otaklah yang berfungsi sebagai bagian dari susunan syaraf yang mengatur dan mengontrol semua aktivitas fisik dan mental seseorang, perkembangan motorik terbagi atas motorik halus dan motorik kasar.

Gerak motorik kasar anak adalah gerakan tubuh yang menggunakan otototot besar atau seluruh anggota tubuh yang dipengaruhi oleh kematangan anak itu sendiri. Tugas perkembangan jasmani berupa kemampuan duduk, menendang, berlari, naik-turun tangga serta koordinasi gerak tubuh seperti berlari, berjinjit, melompat, bergantung, melempar, menangkap dan menjaga keseimbangan. Kegiatan ini diperlukan dalam meningkatkan keterlampilan koordinasi gerak motorik kasar.

Perkembangan gerak motorik kasar ini berkaitan dengan aktifitas fisik/jasmani dengan menggunakan otot-otot besar, seperti otot lengan, otot tungkai, otot bahu, otot pungguang dan otot perut yang di pengaruhi oleh kematangan fisik anak, dan pada umumnya gerakan-gerakan yang bisa dilakukan anak, bisa kita lihat pada saat anak bermaian, anak bermain kesana kemari dengan berlari, melompat, meloncat atau bermain-main dengan bola. Gerakan- gerakan ini sangatlah dipengaruhi oleh perkembangan fisik maupun psikis anak.

Dari buku perkembanagan anak dan buku balita dan perkembanganya menurut Sujiono (2007, hlm. 1.13), menyatakan bahwa:

Perkembanagan motorik anak telah terbagi menjadi dua bagaian, yaitu gerak motorik kasar dan gerak motorik halus. Gerak motorik kasar terbentuk saat anak mulai memiliki koordinasi dan keseimbangan hamapir seperti orang dewasa. Gerakan motorik kasar adalah kemampuan yang

membutuhkan koordinasi sebagian besar bagi tubuh anak.

Oleh karena itu, biasanya memerlukan tenaga karena dilakukan oleh otototot yang lebih besar. Gerakan motorik kasar melibatkan aktivitas otot tangan, kaki, dan seluruh tubuh anak. Gerakan ini mengandalkan kematangan dalam koordinasi. Berbagai gerak motorik kasar yang dicapai anak tentu sangat berguna bagi kehidupannya kelak. Misalnya, anak dibiasakan untuk terampil berlari atau memanjat jika ia sudah besar ia akan senang berolahraga.

Maka untuk mengembangkan kemampuan motorik kasar anak 
menggunakan kegiatan senam ceria yang dimana menurut Peter H. Werner (dalam blog EnsikloPenjas, 2012) mengatakan bahwa, "senam dapat diartikan sebagai bentuk latihan tubuh pada lantai atau pada alat yang dirancang untuk meningkatkan daya tahan, kekuatan, kelentukan, kelincahan, koordinasi, serta kontrol tubuh". Jadi fokusnya adalah tubuh, bukan alatnya, bukan pula pola-pola geraknya, karena gerak apapun yang digunakan, tujuan utamanya adalah pengembangan kualitas terhadap fisik serta penguasaan pengontrolannya.

Sedangkan senam ceria yang di maksud adalah senam yang di modifikasikan dari salah satu kelompok senam yaitu senam irama/ritmik, hal tersebut dikarenakan bahwa senam ritmik adalah gerakan yang dilakukan dengan iringan musik atau latihan bebas yang dilakukan secara berirama.

\section{B. METODE}

1. Desain Penelitian

Desain penelitian yang akan peneliti gunakan adalah model penelitian tindakan kelas Model Elliot. Alasan peneliti menggunakan desain ini karena dalam pengembangan perkembangan fisik motorik kasar melalui kegiatan senam ceria memerlukan waktu yang lama untuk melaksanakan kegiatan tersebut. Sehingga model penelitian tindakan kelas yang cocok yaitu model Elliot, karena model ini terdiri dari beberapa siklus yang tiap siklusnya terdiri dari 3 tindakan.

2. Partisipan dan Tempat Penelitian

Penelitian Tindakan Kelas ini akan dilaksanakan di TK Atikan yang terletak di jalan Riung Wulan No 6, subjek penelitiannya adalah anak Kelompok A, untuk jumlah siswa yang menjadi sumber penelitian yaitu 1 orang perempuan dan 4 orang laki-laki

3. Definisi Operasional

Dalam penelitian tindakan kelas (PTK) ini yang menjadi fokus penelitian yaitu motorik kasar anak dan kegiatan senam ceria.

Motorik kasar anak adalah gerakan tubuh yang menggunakan otot-otot besar dan seluruh anggota tubuh yang dipengaruhi oleh kematangan anak itu sendiri. motorik kasar ini merupakan bagian dari aktivitas atau keterlampilan dari otot-otot besar. Sehingga dengan bertambahnya usia anak, maka kematangan syaraf dan otot anak berkembang pula.

Senam ceria yang di maksud adalah senam yang di modifikasikan dari salah satu kelompok senam yaitu senam irama/ritmik, hal tersebut dikarenakan bahwa senam ritmik adalah gerakan yang dilakukan dengan iringan musik atau latihan bebas yang dilakukan secara berirama. Irama adalah gerakan yang ${ }^{l}$ penulis penanggung jawab ${ }^{2}$ penulis penanggung jawab dilakukan diiringi musik ataupun lagu-lagu. Adapun pada aktivitas ritmik ada tiga hal yang harus diperhatikan, yakni fleksibilitas, kontinuitas, dan ketepatan dengan irama. Dengan senam ceria ini senam yang diiringi musik yang ceria sehingga anak ketika sedang melakukan senam anak akan aktif, ceria dan menyenangkan dengan irama musik yang mengiringinya ketika sedang senam. Dalam kegiatan senam ceria ini peneliti dapat melihat perkembangan pada motorik kasar anak sesuai dengan indikator yang telah ditetapkan oleh peneliti seperti:

1. Mengikuti gerakan senam sesuai dengan irama 
2. Menggerakan kepala, tangan dan kaki secara terkoordinasi sesuai irama

3. Mengekspresikan gerakan senam sesuai dengan irama music.

4. Instrumen Penelitian

Instrumen ini digunakan dalam penelitian untuk mengumpulkan data-data selama peneliti melaksanakan penelitian. Instrumen yang digunakan dalam penelitian ini antara lain penilaian performa, lembar observasi, wawancara, catatan lapangan. serta dokumentasi,

5. Teknik Pengumpulan Data

Teknik pengumpulan data yang digunakan dalam menunjang kegiatan penelitian ini antara lain: Teknik tes, teknik observasi, teknik wawancara, dan dokumentasi.

6. Teknik Analisis Data

Teknik pengumpulan data yang digunakan dalam penelitian kali ini yaitu teknik pengolahan data yang dilakukan melalui deskripsi terhadap seluruh proses kegiatan penelitian. Proses analisis data dilakukan dengan mengumpulkan informasi atau data dari berbagai sumber seperti catatan lapangan, dokumentasi, wawancara, lembar observasi, dan dokumentasi siswa pada setiapp siklusnya yang dapat diolah sehingga mengetahuai hasil yang akan dicapai siswa.

Analisis data dilakuakn terhadap seluruh data yang didapatkan dari semua instrumen selama penelitian dilaksanakan. Data yang diperoleh dalam penelitian adalah bersifat kualitatif dan kuatitatif. Data kuantitatif diperoleh dari hasil observasi dan penilaian performa/proses, untuk mengetahui tingkat pencapaian anak, data yang telah diperoleh dari hasil observasi dihitung melali presentase dan analisis data kuantitatif yang digunakan dengan mencari rata-rata.

Data kualitatif merupakan data yang dikumpulkan dari kegiatan guru, wawancara, dokumentasi dan cacatan lapang. Data tersebut diolah melalui tahapan yakni klasifikasi, analisis dan penafsitan. Pengujian validitas penelitian yang dilakukan dengan cara mengolah data yang diperoleh kemudian dengan sumber yang mengumpilkan data.

Data yang dianalisis secara komunikatif digunakan untuk menentukan peningkatan untuk menentukan peningkatan hasil belajar anak dilihat dari setiapp tindakan yang dilakukan oleh anak, untuk melihat peningkatan belajar anak dapat dilihat dariperorangan. Kegiatan senam ceria dapat dikatakan berhasil dalam meningkatkan keterlampilan motorik kaasar anak jika anak sudah memenuhi segala tingkat pencapaian dengan baik maka akan mendapatkan bintang sebanyak 4 .

Maka dari itu menghitung persentase ketuntasan tersebut yaitu dengan menggunakan rumus:

\section{Skor yang diperoleh anak
Persentase (\%) :
Jumlah Anak $100 \%$}

Terkait dengan kualitas data dapat dijelaskan bahwa analisis data dilakukan dengan cara sistematis dari hasil pengamatan dan tindakan kelas sehingga diperoleh deskripsi data utuh, maka dari itu dapat di lakuakn dangan teknik tringulasi.

Triangulasi adalah teknik analisis data yang digunakan untuk menguji keabsahan data selama penelitian. Penulis menggunakan beberapa cara untuk 
menguji keabsahan data yang ditemukan melalui teknik analisis data kuantitatif dan kualitatif sehingga disebutlah teknik triangulasi. Jadi teknik analisis data triangulasi merupakan perpaduan analisis data kuantitatif berserta kualitatif sehingga data yang didapat lebih akurat.

\section{PEMBAHASAN}

Penelitian tindakan kelas ini dilaksanakan di TK Atikan yang terletak di Kecaman Gedebage Kota Bandung dan penelitian ini dilakukan pada kelas A yang terdiri 5 orang jumlah siswa yang diantaranya 1 orang anak perempuan dan 4 orang nak laki-laki. Disini peneliti berperan sebagai guru inti di dalam kelas, sedangkan guru pamong berperan sebagai observer, tugas seorang observer yaitu menilai penampilan peneliti selama proses belajar mengajar berlangsung. Pada kegiatan ini, peneliti ingin mengembangkan kemampuan fisik motorik kasar anak melalui kegiatan senam Ceria.

Sesuai dengan tujuan penelitian tindakan kelas, yaitu mengembangkan dan mengembangkan praktik pembelajaran yang dilaksanakan di lapangan, kegiatan senam ini dilakukan pada anak diiringi dengan musik dandilakukan pada setiapp tindakan. Pada setiapp tindakan bertujuan untuk melatih gerakan dasar yang dilakukan oleh anak seperti gerakan lokomotor dan non-lokomotor melalui gerakan yang melibatkan koordinasi antara tangan, kaki dan kepala. Melakukan kegiatan senam ceria ini merupakan kegiatan tambahan pada kegiatan inti, dan waktu yang dibutuhkan \pm 30 menit untuk melaksanakan kegiatan ini. Secara lengkap dapat dilihat pada Rencana Kegiatan Harian (RKH) yang telah dirancangpeneliti pada lampiran. Kemudian selanjutnya kegiatan senam ini dilakukan melalui refleksi pada setiapp siklusnya. Adapun dilakukannya refleksi pada siklus pertama adalah sebagai upaya untuk melakukan perbaikan pada tindakan selanjutnya untuk memperbaiki siklus yang belum mencapai indikator yang telah diajukan.

Pada setiapp kegiatan senam ceria setiapp siklusnya dilakukan di luar sekolah dan sebelum keluar anak-anak selalu di kondisikan agar tertib ketika keluar kelas, setelah berada diluar kelas sebelum melakukan senam guru mengajak anak untuk membuat lingkaran dan bernyanyi terlebih dahulu setelah itu anak-anak dikondisikan pada posisi senam ceria karena jumlah anak yang mengikuti senam ceria berjumlah 5 anak maka posisi senam seperti berikut.

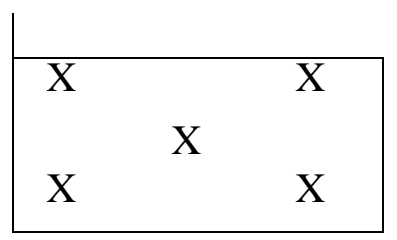

Setiap senam ceria ini dilakukan berulang-ulang agar anak dapat ingat tetapi terdapat waktu istirahat atau jeda,pada waktu tersebut guru secara tidak langsung dapat mewawancarai atau bertanya jawab mengenai kegiatan senam ceria ini.

Pada siklus I, kegiatan senam ceria dilakukan di luar sekolah dan kegiatan senma ceria pada siklus I ini diiringi dengan ketukan tamborin pada setiapp gerakan yang telah di contohkan oleh guru, kemudian anak-anak mengikuti gerakan senam 
tersebut bersama-sama.

Dalam memberikan kegiatan yang dapat mengembangkan kemampuan motorik kasar anak, peneliti memilih kegiatan senam pada anak karena dalam melakukan senam semua bagian tubuh anak dapat bergerak dan dapat terkoordinasikan antara tangan, kepala dan kaki dan bergerak mengikuti irama sehingga dapat mengembangkan kemampuan motorik anak dengan baik, sejalan dengan pendapat sujiono (2007, hlm, 1.13) yang mengatakan "motorik kasar sebagai kemampuan gerak yang dapat dilakukan oleh seluruh tubuh secara terkoordinasi". Sedangka senam merupakan gerakan atau kombinasi beberapa gerakan yang disusun secara sistematis untuk mencapai kondisi tubuh yang sehat (Neggala, 2007, hlm, 60). Sedangkan senam ceria merupakan senam yang diiringi dengan musik yang ceria sehingga dalam melakukan kegiatan senam anak-anak semangat dan ceria.

Pada siklus II, kegiatan senam ceria yang dilakukan di lur sekolah ini dengan menggunakan irama musik atau lagu yang telah guru siapkan kemudian anak-anak mengikuti gerkan senam ceria ini dengan iringan musik.

Pada saat ana-anak tampil guru selalu memberikan reward atau pujian kepada anak. karena dengan memberikan pujian atau reward maka anak akan mengalami pengembangan kearah lebih baik, hal tersebut sejalan dengan pendapat Sumantri dan Syaodih (2007, hlm. 2.40) yang mengatakan "ganjaran dan hadiah sebagai bentuk apresiasi atau penghargaan terhadap suatu prestasi yang dicapai oleh suatu atau sekelompok anak dalam aktivitas tertentu". yang berupa pemberian bintang, hadiah dan pujian yang diberikan oleh guru kepada anak-anak yang dapat melakukan kegiatan yang telah diberikan guru.

Pada siklus III, kegiatan senam ceria yang dilakukan dengan iringan musik seperti pada siklus II dan diberi properti pada masing-masing anak, seperti pada tindakan 1 anak memakai gelang lonceng, pada tindakan 2 anak memakai gelangkakilonceng dan pada tindakan 3 anak memakai topi kartun, properti yang dilakukan pertindakannya ditambah sehingga pada tindakan 3 anak-anak memakai semua properti yang telah guru berikan.

Serta pada kegitan senam ceria menggunakan properti karena mediamempunyai peran penting dalam mengembangkan motivasi anak dalam mengikuti kegiatan pembelajaran, hal ini sejalan dengan pendapat Hamalik (dalam Deltanti, 2014, hlm, 118) bahwa "pemakaian media belajar dalam proses belajar mengajar dapat membangkitkan keinginan dan minat yang baru, membangkitkan motivasi dalam kegiatan belajar, bahkan membawa pengaruh- pengaruh psikologis terhadap anak".

kemampuan motorik kasar anak dikelompok A sudah meningkat, kegiatan senam ceria yang dilakukan pada siklus III yaitu menggunakan properti sepasang gelang lonceng, gelang kaki lonceng dan topi kartu, pada tindakan tiga ini anakanak tertib dan fokus saat mengikuti gerakan senam dan anak sudah dapat mengikuti gerakan senam, menggerakan anggota tubuhnya secara terkoordinasi dan mampu mengekspresikan gerakan senam sesuai irama sesuai dengan pendapat Mutia (dalam Nurlitasari, 2014 hlm, 25)mengatakan bahwa :

Gerakan yang erat hubungannya dengan musik merupakan isyarat yang ekspresif dan membebaskan diri dari ketegangan melalui gerakan-gerakan 
ritmis, sehingga penanganan anak yang berperilaku agrefis, media gerak ritmis dapat menyalurkan emosi-emosi negatif dengan cara yang dapat di terima oleh lingkungannya.

Berikut secara lebih jelasnya akan dipaparkan grafik dan narasi pengembangan kemampuan motorik kasar anak melalui kegiatan senam ceria yang dilakukan selama III silkus dan 3 tindakan dan akan di jelaskan secara terperinci adapun sebagai berikut:

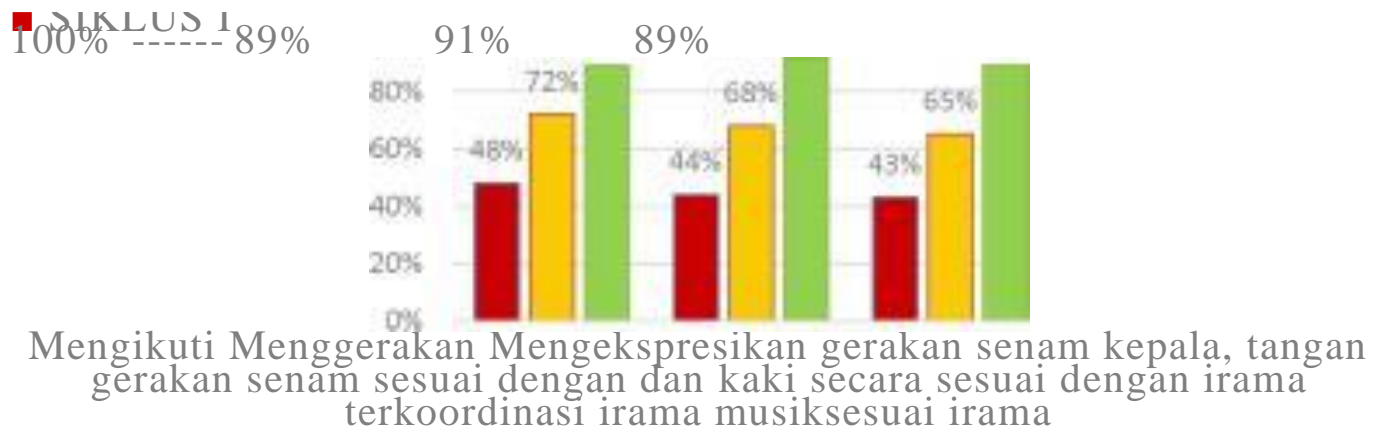

\section{Gambar 4.1 Performa kemampuan motorik kasar anak pada siklus I-III}

Grafik ini menjelaskan mengenai pengembangan motorik kasar anak selama persiklus dari masing-masing indikator yang telah dligunakan. Berdasarkan grafik performa, dapat terlihat pengembangan motorik kasar anak melalui kegiatan senam ceria mengalami pengembangan pada setiapp siklusnya pada indikator pertama yaitu mengikuti gerakan senam sesuai irama dari siklus $1(48 \%)$, siklus II (72\%), siklus III (89\%) mengalami selisis pengembangan yang cukup yaitu pada siklus I ke siklus II (24\%).

Pada indikator menggerakan kepala, tangan dan kaki secara terkoordinasi sesuai irama mengalami pengembangan yang baik dari siklus I ( $44 \%$ ), siklus II $(68 \%)$, siklus III (91\%). Pada indikator kedua ini pengembangan antara siklus I,II, dan III cukup baik karena pada setiapp siklusnya kegiatan senam ceria ini berbedabeda menggunakan alat untuk irama musiknya, seperti pada siklus I irama yang di pakai menggunakan irama tamborin, siklus II menggunakan irama musik sehingga anak dapat menggerakan anggota badannya secara terkoordinasi sesuai dengan irama yang telah guru sediakan, dan untuk siklus III anak semangat menggerakan anggota badannya secara terkoordinasi karena diiringi musik dan di pakaikan properti pada dirinya sehingga anak bersemangat, antusias dalam kegiatan senam ini.

Pada indikator mengekspresikan gerakan melaui senam ceria mengalami pengembangan pada setiapp siklusnya dari siklus I (43\%), siklus II (65\%), siklus III (89\%), pada siklus II ke siklus III mengalamin pengembangan yang cukuk baik, hal ini didukung oleh perbaikan yang dilakukan pada setiapp siklusnya terutama siklus II, sehingga pembelajaran pada siklus III dapat meningkatkan ekspresi gerakan senam pada anak, pada siklus I kegiatan senam hanya menggunakan irama tamborin saja sehingga itu belum menarik perhatian anak untuk mengikuti gerakan 
senam secara ekspresif, jika pada siklus II menggunakan musik anak mulai ada pengembangan dalam mengekspresikan gerakan memalui senam, dan pada siklus III sudah ada pengembangan dalam mengekspresikan gerakan melaui senam ini karena pada siklus III anak di berikan properti seperti gelang lonceng, gelang lonceng kaki dan topi kartun, sehingga anak lebih bersemangat, lincah dan antusias.

\section{Dalam indikator mengikuti gerakan senam sesuai dengan irama}

Rata-rata kemampuan motorik kasar anak setelah mengikuti kegiatan senam ceria sesuai indikator mengikuti gerakan senam sesuai dengan irama pada siklus I yaitu 1,93 yang berati anak mulia mengalami pengembangan kemampuan motorik kasar walau pun masih ahrus di bimbing oleh guru dan harus selalu di berikan motivasi, pada siklus ke II, mulai terjadi pengembangan rata-rata kemampuan motorik kasar anak sebesar 2,87, hal ini berarti anak mulai termotivasi dan mulai antusisias saat mengikuti kegiatan senam ceria, sedangkan pada siklus III, rata-rata pengembangan kemampuan motorik kasar anak meningkat sebesar 3,57 nilai rata-rata tersebut cukup meningkat, hal ini berarti anak di kelompok A mengalami pengembangan kemampuan motorok kasar dengan baik, meskipun belum semua anak mengalami pengembangan pada mengikuti gerakan senam sesuai irama.

\section{Dalam indikator menggerakan kepala, tangan dan kaki secara terkoordinasi sesuai irama}

Rata-rata kemampuan motorik kasar anak setelah mengikuti kegiatan senam ceria berdasarkan indikator diatas pada siklus I yaitu 1,77 yang berarti anak mulai mengalam pengembangan kemampuan motorik kasar namun pada siklus ini anak masih selalu di bimbing dan diberi motivasi olehguru, sedangkan pada siklusII, anak mulai mengalami pengembangan rata-rata kemampuan motorik kasar anak yaitu sebesar 2,72 pada siklus ke II ini anak mengalami pengembangan saat menggerakan anggota badannya secara terkoordinasi karena pada siklus ini kegiatan senam ceria menggunakan musik sehingga anak mulai dapat termotivasi mengikuti gerakan senam ceria ini sehingga anak dapat menggerakan seluruh anggota badannya baik tangan, kaki dan kepala walaupun terdapat beberapa anak yang masih harus di bimbing, sedangkan pada siklus III, rata-rata pengembangan kemapuan motorik kasar di kelompok A yaitu 3,63 pada siklus III ini anak-anak sudah meningkat dan sudah dapat menggerkan anggota tubuhnya secara terkoordinasi antara tangan, kaki dan kepala dengan semangat dan lincah dan tepat walaupun masih saja terdapat anak yang masih dibimbing oleh guru.

Rata-rata kemampuan motorik kasar anak setelah mengikuti kegiatan senam ceria pada indikator ini pada siklus I yaitu 1,78 yang berarti pada siklus ini anak mulai mengalami pengembangan dalam mengekspresikan gerakan sesuia irama dengan sungguh-sungguh dan antusias dibandingkan kegiatan senam sebelumnya melaksanakan tindakan, pada siklus II anak mulai mengalami pengembangan dalam menekspresikan gerakan sesuai irama denga rata-rata 2,58 hal ini terjadi 
pada siklus II peniliti menggunakan lagu sebagai irama musiknya sehingga anak mulai antusias dan berani dalam mengekspresikan geraknnya, namun masih terdapat anak yang masih belum berani dan ceria, sedangkan pada siklus III anakanak sudah meningkat dalam kemampuan motorik kasar anak di bandingkan pada siklus sebelumnya sebesar 3,55 peningktan motorik kasar anak pada siklus ini karena peneliti menggunakan berbagai properti seperti yang telahdi sebutkan sebelumnya sehingga anak-anak termotivasi dalam mengekspresikan gerakan sesuai dengan irama musik. Namun pada siklus III masih ada satu anak yang masih belum luwes dan lemas saat melakuakan senam ceria ini.

\section{PENUTUP}

Proses kegiatan senam ceria yang dilaksanakan di TK Atikan yang dilakukan melalui III siklus dan 3 tindakan. Pada kegiatan senam ini anak-anak distimulus agar dapat meningkatkan kemampuan motorik kasar dengan lincah, luwes, semangat dan tepat. Pada kegiatan senam ceria siklus I belum terdapat banyak pengembangan pada anak, kemudian kegiatan senam siklus II mulai pengembangan motorik kasar pada anak. pada siklus III kegiatan senam ceria ini sudah terdapat pengembangan pada kemampuan motorik kasar pada anak dikelompok A pada kegiatan senam ceria siklus III anak terlihat semangat, ceria, lincah dan luwes saat melakukan cenam ceria. Pada setiapp siklusnya terdapat pengembangan kemampuan motorik kasar pada anak, hal ini terjadi karena pada siklus I peneliti hanya menggunakan irama dan ketukan tamborin, pada siklus II peneliti menggunakan lagu/musik untuk mengiringi anak saat sedang senam, sedangkan padasiklus III peneliti menggunakan properti/ media pada anak saat melakukan senam, seperti gelang lonceng, gelang kaki lonceng dan topi kartun, sehingga anak mulian meningkat kemampuan senam ceria yang telah dilakukan oleh peneliti, serta pemberian motivasi dan reward yang diberikan sehingga anakanak antusias mengikuti kegiatan senam ini.

Hasil dari kemampuan motorik kasar anak setelah mengikuti kegiatan senam ceria mengalami pengembangan. Hal tersebut terlihat pada indikator 1 yaitu mengikuti gerakan senam sesuai dengan irama, pada siklus I mencapai $48 \%$, siklus II mencapai $72 \%$, siklus III 89\%. Pada indikator ke 2 yaitu menggerakan kepala, tangan dan kaki secara terkoordinasi sesuai irama, siklus I mencapai $44 \%$, silus II mencapai $68 \%$ dan pada siklus II mencapai $91 \%$. Sedangkan pada indikator ke 3 yaitu mengekspresikan gerakan senam sesuai dengan irama musik, siklus I mencapai 43\%, silus II mencapai 65\% dan siklus III mencapai 89\%. Berdasarkan hasil setiapp indikator ini, maka kegiatan melalui senam ceria dapat meningkatkan kemampuan motorik kasar pada anak di kelompok A TK Atikan.

\section{DAFTAR PUSTAKA}

Abidin, Y. (2009). Bermain. Bandung: Rizqi Press

Deltanti. R. (2014). Peningkatan Kemampuan Motorik Kasar Anak Usia Dini Melalui Tarian Kreasi. Sekolah Sarjana, Universitas Pendidikan Indonesia, Bandung.

Ensiklo Penjas, ( 2012). Pendidikan Jasmani. [Online]. Diakses dari. http://pendidikanjasmani13.blogsp ot.com/ 2012/ 05/ pengertian senam. html 
Nenggala, Asep, K. (2007) Pendidikan Jasmani dan Kesehatan. Jakarta : Grafindo Media Pratama

Nenggala, Asep, K. (2007) Pendidikan Jasmani dan Kesehatan. Jakarta : Grafindo Media Pratama

Nurlitasari, T, (2014). Meningkatkan Rasa Percaya Diri Anak Melalui Kegiatan Ekspresi Seni Gerak dan Lagu. (Skripsi). Sekolah Sarjana, Universitas Pendidikan Indonesia, Bandung.

Sujiono Bambang, dkk. (2007). Metode Pengembangan Fisik. Jakarta: Universitas Terbuka

Sumantri, Syaodi (2007). Perkembangan Peserta Didik. Jakarta: Universitas Terbuka 